\title{
Akutní perikarditida
}

\author{
Jan Lhotský, Milan Hromádka, Vratislav Pechman, Ondřej Sirotek, Richard Rokyta \\ Kardiologická klinika, Centrum vysoce specializované komplexní kardiovaskulární péče FN Plzeň, LF Plzeň, \\ Univerzita Karlova, Plzeň
}

Jedná se o přehledový článek, který se zabývá klinickými projevy, diagnostikou, rizikovou stratifikací a léčbou akutní perikarditidy.

Klíčová slova: akutní perikarditida, diagnostika, elektrokardiogram, léčba, nesteroidní antirevmatika, kolchicin.

\section{Acute pericarditis}

This article reviews the clinical presentation, diagnostic evaluation, risk stratification, and treatment of acute pericarditis.

Key words: acute pericarditis, diagnosis, electrocardiogram, treatment, non-steroidal anti-inflammatory drugs, colchicine.

Akutní perikarditida (AP) je zánětlivý perikardiální syndrom s nebo bez perikardiálního výpotku zpưsobený infekční nebo neinfekční příčinou (1). Jde celosvětově o nejčastější onemocnění perikardu. V Evropě a USA tvoří 0,1-0,2\% ze všech prijetí k hospitalizaci pro kardiovaskulární diagnózu a přibližně $5 \%$ ze všech emergentních vyšetření pro neischemickou bolest na hrudi. Častěji postihuje muže a dospělé jedince mladé a střední věkové skupiny (2).

\section{Etiologie}

$\checkmark$ rozvinutých zemích je více než $80 \%$ epizod AP idiopatických (etiologie není určena) a předpokládá se, že převážná část z nich je virové etiologie (enteroviry, herpetické viry, HIV aj.). V rozvojových zemích a celosvětově je nejčastější prričinou tuberkulóza. Ve vyspělých zemích pribývá prípadů tzv. syndromu poškození perikardu, který zahrnuje perikarditidu po infarktu myokardu, post-perikardiotomický syndrom a posttraumatickou perikarditidu (včetně iatrogenního poranění při perkutánních koronárních intervencích, radiofrekvenčních ablacích aj.). Etiologie AP dále může být autoimunitní (systémový lupus erytemotodes, revmatoidní artritida aj.), neoplastická (zejména metastatic- ká postižení perikardu - karcinomy plic či prsu, lymfomy, melanom), radiační, uremická či bakteriální (purulentní perikarditida - zejména stafylokoky) (1, 3).

Pacienti s virovou či idiopatickou AP mají dobrou dlouhodobou prognózu. Rekurence se objeví asi u 15-30 \% postižených (1) a k rozvoji tamponády či konstrikce dochází zřídka. Riziko uvedených komplikací je ale mnohem větší u nemocných s "neidiopatickou či nevirovou" etiologií (malignity, TBC, purulentní perikarditida).

\section{Diagnóza}

Ke stanovení diagnózy AP by měla být splněna alespoň dvě z kritérií uvedených $\vee$ tabulce 1. Podpůrnými nálezy mohou být zvýšené zánětlivé markery (CRP, leukocyty) či zánětlivé postižení perikardu prokázané výpočetní tomografií (CT) či magnetickou rezonancí (MR) (1).

Při současném postižení myokardu se mluví o myoperikarditidě nebo perimyokarditidě. U myoperikarditidy převládá perikarditida. Jsou zvýšené hodnoty myokardiálních markerů (troponin, (K), ale není porucha funkce levé komory při echokardiografickém vyšetření či MR. Při perimyokarditidě dominuje myokarditida (je nově vzniklé fokální nebo difuzní poškození funkce levé komory).

\section{Manifestace}

Více než 85-90\% nemocných s AP udává bolest na hrudi. Ta má typicky náhlý začátek a je lokalizována na přední ploše hrudníku. Na rozdíl od myokardiální ischemie jde nejčastěji o ostrou bolest pleuritického charakteru se zhoršením v inspiriu, při kašli a v leže. Ke zmírnění dochází naopak při předklonění a posazení. Za specifickou pro AP bývá považována iradiace bolesti do kraniální části m. trapezius. Nicméně také u AP se může vyskytovat tupá bolest nebo její iradiace do ramen, končetin či krku a její odlišení od ischemické bolesti může být obtížné $(4,5)$. Bolest může být minimální nebo chybět u pacientů s uremickou etiologií či u AP v rámci revmatického onemocnění.

Častými symptomy v prípadě idiopatické či virové AP jsou subfebrilie, únava, dušnost, kašel a myalgie. Velká část nemocných má v predchorobí projevy akutní respirační virózy.

Tab. 1. Diagnostická kritéria AP
- Typická bolest na hrudi
- Perikardiální třecí šelest
- EKG známky AP
- Nový či zhoršený perikardiální výpotek 
Tab. 2. Prediktory horší prognózy u AP

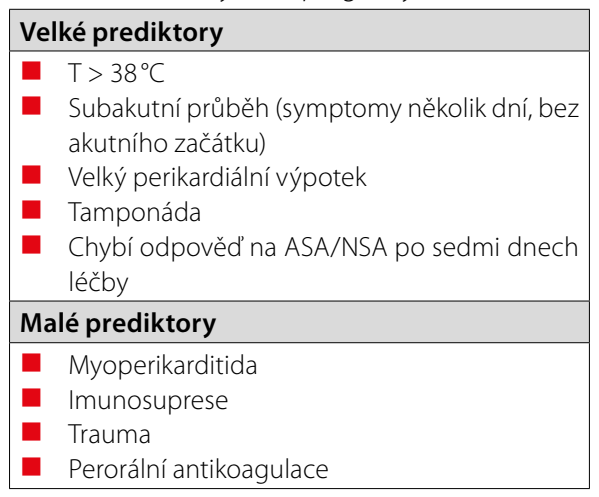

Pro purulentní perikarditidu je charakteristický fulminantní průběh s výraznými febriliemi a zimnicí. Naopak tuberkulózní perikarditida mívá průběh chronický se subfebriliemi.

\section{Perikardiální třecí šelest}

Perikardiální třecí šelest je vrzavý zvuk („„chůze po zmrzlém sněhu") vysoce specifický pro AP. Je nejlépe slyšitelný v předklonu na levé dolní straně sterna. Může být tvořen až třemi komponentami, jež odpovídají pohybům srdce během systoly komor, rychlého komorového plnění a systoly síní. Na rozdíl od pleurálního šelestu není vázaný na dýchání. Jeho charakter i intenzita bývá v čase výrazně proměnlivá a k jeho odhalení mohou být nutné opakované auskultace.

\section{EKG}

EKG může u AP projít čtyřmi stadii: 1) difuzní elevace úseků ST a deprese úseků PR, 2) normalizace, 3) difuzní inverze vln T, 4) normalizace nebo perzistující inverze vin T. Vývoj EKG změn v čase ale může být vysoce variabilní $(4,5)$. U některých pacientů dokonce EKG změny nemusí být prítomny. Za typické EKG známky AP bývají považovány zejména difuzní ST elevace a PR deprese (obrázek 1). $\checkmark$ praxi je zásadní odlišení těchto změn od akutního koronárního syndromu (AKS). Diagnózu AP podporují ST elevace s nahoru směřující konkavitou, které nepřekračují výšku 5 mm a nejsou omezeny na povodí jedné koronární tepny (pozor na možnost "difuzních“ ST elevací u AKS při uzávěru RIA, která přechází přes hrot na spodní stěnu). Dále je to neprítomnost kontralaterálních ST depresí (s výjimkou aVr a V1), obraz elevace PR v aVR s depresemi PR v ostatních svodech, chybění patologických Q a vznik inverze vln Taž po normalizaci ST úseku (tj. ST elevace a inverze T se nevyskytují v jedné době). Pokud není současně prítomna myokarditida, je riziko arytmií u AP nízké.
Obr. 1. Typické EKG u AP s difuzními ST elevacemi a PR depresemi

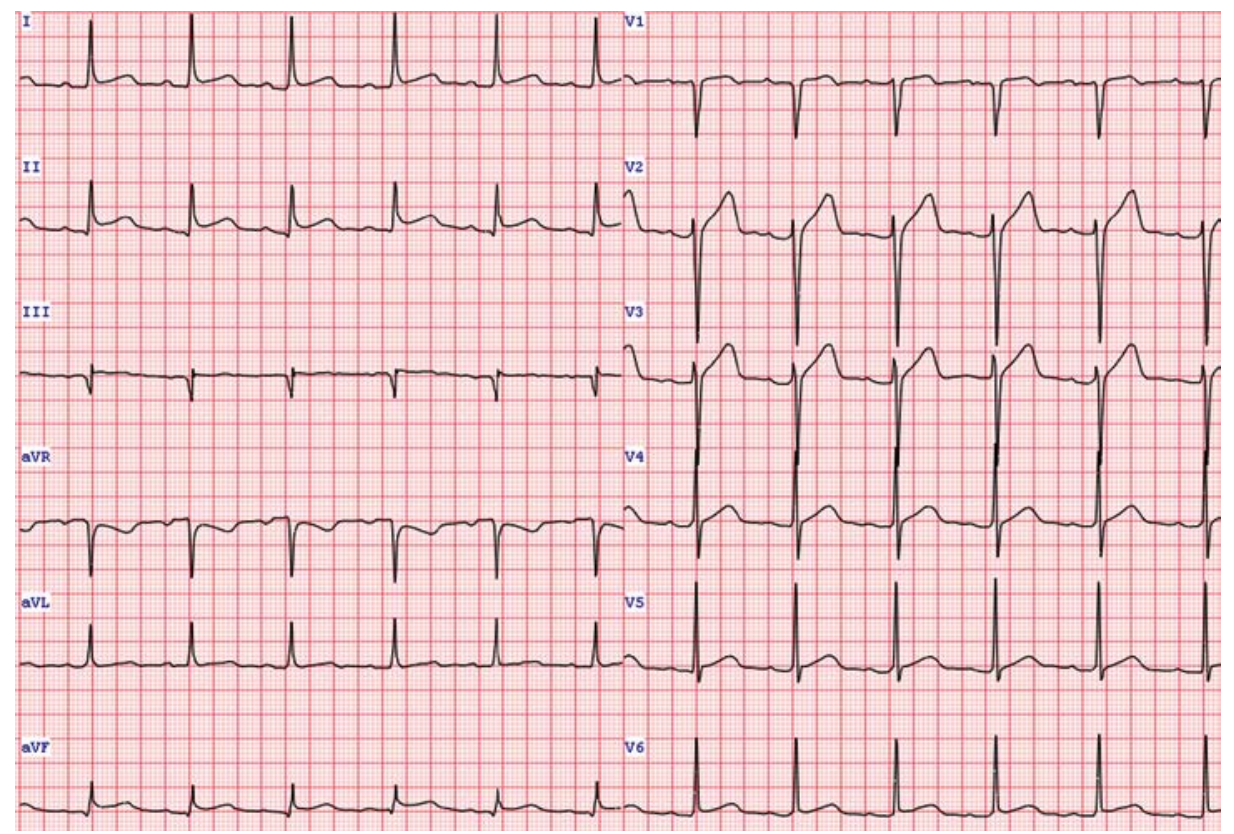

\section{Zobrazovací metody}

Zobrazovací metodou první volby je transtorakální echokardiografické vyšetření (TTE). Mělo by být součástí vstupního vyšetření (během prvních 24 hodin) všech pacientů s AP. Echokardiografický nález je u řady nemocných s akutní perikarditidou normální. Až u 60 \% pacientů je patrný perikardiální výpotek, který je nejčastěji malý (obrázek 2) (6). Echokardiografie hraje významnou roli v diagnostice komplikací (konstrikce, tamponáda, postižení myokardu). Někdy může pomoci s určením etiologie perikardiálního postižení (např. zobrazení tumoru) nebo častěji s diferenciální diagnostikou stavů, které mohou AP napodobovat (např. regionální porucha kinetiky v povodí uzavřené koronární arterie u AKS, disekce aorty, plicní embolie apod.).

CT a MR vyšetření mohou podpořit diagnózu perikarditidy při pochybnostech (např. atypické manifestace, bolest na hrudi bez zvýšení (RP). MR umožňuje zhodnocení perikardiálního zánětu. Zanícený perikard je světlý a ztluštělý v T2 váženém zobrazení (edém) a sytí se po injekci kontrastu (pozdní sycení gadoliniem). Zároveň může být popsána současná myokarditida. Při CT vyšetření je pro AP sugestivní nekalcifikované ztluštění perikardu s perikardiálním výpotkem. Navíc při podání jodové kontrastní látky může dojít k nasycení („enhancementu“) ztluštělého zaníceného viscerálního a parietálního perikardu. CT může také pomoci v diferenciální diagnostice exsudátu (20-60 Hounsfieldových jednotek) a transudátu (méně než 10 Hounsfieldových jednotek) (7), v určení možné příčiny perikarditidy (Ca plic, TBC) a v posouzení koronárních tepen.

\section{"Základní algoritmus"}

U všech nemocných s AP, či podežrením na ni, se doporučuje provést EKG, TTE, rtg plic, markery zánětu (CRP, leu) a postižení myokardu (troponin, CK) a laboratorní vyšetření funkce ledvin, jater a štítné žlázy (tzv. testy první linie) (1). V zemích s nízkou prevalencí TBC není nutné (vzhledem k relativně benignímu průběhu idiopatické formy) pátrání po etiologii AP u všech nemocných. Je ale nezbytné vstupně vytřídit nemocné s podezřením na "neidiopatickou či

Obr. 2. Malý perikardiální výpotek U AP (anechogenni prostor pred pravou komorou a za zadní stěnou levé komory - označený šipkami)

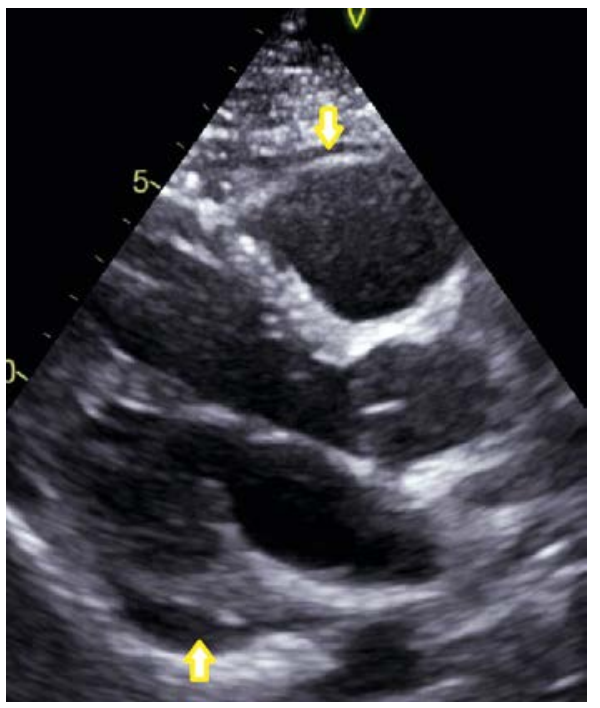


nevirovou" etiologii a s prítomností jakéhokoliv z prediktorů horší prognózy (tabulka 2). U těchto rizikových pacientů je indikováno príjetí k hospitalizaci a určení etiologie AP. Ostatní nemocní (s nízkým rizikem) mohou být léčení v domácím prostředí s ambulantní kontrolou odpovědi na léčbu za jeden týden.

\section{Stanovení etiologie}

Pokud není u rizikových pacientů etiologie AP zřejmá z úvodních vyšetření, je nutné provedení doplňujících testů (tzv. druhé linie). Důležitou úlohu může hrát CT či MR vyšetření (ve vybraných prípadech v kombinaci s pozitronovou emisní tomografií - PET). Mezi vyšetření krve mohou patřit opakované hemokultury před nasazením ATB, sérologická vyšetření na HIV, virus hepatitidy $C$ či borrelie (při podezření na lymeskou nemoc), Quantiferon test (při možnosti TBC) a stanovení autoprotilátek (ANA, ENA, ANCA, revmatoidní faktor). Sérologická vyšetření k určení jiných virových agens jsou v současné době provažována za neprínosná.

Rozhodující v určení příčiny AP může být vyšetření perikardiálního výpotku. Perikardiocentéza (př́p. chirurgická drenáž) je indikována při srdeční tamponádě, při suspekci na nádorovou či tuberkulózní perikarditidu nebo u symptomatických pacientů se středním nebo velkým výpotkem refrakterním na medikamentózní léčbu. Perikardiální výpotek bývá zpravidla odesílán na biochemické, cytologické, mikrobiologické vyšetření, k provedení polymerázové retězové reakce $(P C R)$ a event. ke stanovení biomarkerů (8). Součástí biochemického vyšetření je určení specifické hmotnosti, koncentrace celkové bílkoviny, LDH, poměru koncentrace bílkoviny výpotek/sérum a poměru koncentrace LDH výpotek/sérum (pro exsudát svědčí hodnoty větší než 1015, 30 g/l, 2 g/l, 0,5 a 0,6). U purulentní perikarditidy výrazně klesá koncentrace glukózy ve výpotku a je nízký poměr její koncentrace výpotek/sérum (střední hodnota 0,3). U tuberkulózní etiologie je střední hodnota tohoto poměru 0,7 a u nádorové 0,8. (9). Výsledkem cytologického vyšetření perikardiálního výpotku může být přitomnost nádorových buněk. Príměs erytrocytů v exsudátu bývá u nádorových, tuberkulózních, purulentních, postperikardiotomických a uremických výpotků. Počet leukocytů stoupá u zánětlivých výpotků a naopak klesá u myxedému. Provádí se také diferenciální rozpočet leukocytů. Zvýšení monocytů nacházíme u malignit a myxedému. Pro purulentní perikarditidu je charakteristické vysoké zastoupení neutrofilů (92\%). U tuberkulózní a neoplastické príčiny se uvádí podíl neutrofilů 50 \% a 55 \% (9). Zvýšený poměr lymfocytů proti mononukleárům je u autoreaktivního výpotku. Mikrobiologické vyšetření spočivá v aerobních, anaerobních, tuberkulózních a ev. mykotických kultivacích. PCR může být specificky cílené na genom TBC či kardiotropní viry. Z biomarkerů, které se stanovují z perikardiálního výpotku, je možné zmínit adenozin deaminázu a interferon- $\gamma \vee$ diagnostice TBC či tumorové markery (např. CEA, CYFRA 21-1).

U vybraných prípadů s podežrením na nádorovou, tuberkulózní či bakteriální perikarditidu může být zvážena perkutánní nebo chirurgická biopsie perikardu (1).

\section{Léčba}

Pro pacienty s akutní idiopatickou nebo virovou perikarditidou je doporučena léčba kyselinou acetylsalicylovou (ASA) nebo nesteroidními antirevmatiky (NSA) v kombinaci s kolchicinem. Do ústupu aktivního onemocnění má být omezena fyzická aktivita (u závodních sportovců minimálně tři měsíce, při současném postižení myokardu šest měsíců). Uvedená časová doporučení jsou však založena pouze na názorech expertů. Například dle našich zkušeností mají nemocní s akutní myokarditidou, která není doprovázena poruchou funkce levé komory, dobrou prognózu i při krátkodobější restrikcí fyzické aktivity (10).

Řada pracovišt vzhledem k dobrému bezpečnostnímu profilu preferuje ibuprofen. Použití ASA by mělo být upřednostněno u nemocných s ICHS, jinou indikací antiagregační léčby nebo již léčených ASA. Indometacin má dobrou účinnost, ale více nežádoucích účinků, a je proto obvykle zvažován až pro rekurence. Navíc snižuje průtok koronárním řečištěm a neměl by být podáván pacientưm s ICHS. Uvedené léky by měly být užívány $v$ príślušné protizánětlivé dávce do vymizení symptomů a normalizace CRP. Všechny se užívají po 8 hodinách (ASA 750-1 000 mg a 8 hod., ibuprofen 600 mg a 8 hod., indometacin 50 mg a 8 hod.). U nekomplikovaných prípadů trvá terapie plnou dávkou 1-2 týdny a následně je podle vývoje zvažováno postupné vysazování léku. Součástí léčby je gastroprotekce inhibitory protonové pumpy (1). Kontraindikací ASA/NSA může být alergická reakce v minulosti, recentní vředová choroba gastroduodena nebo krvácení do zažívacího traktu či orální antikoagulační léčba s vysokým rizikem krvácení.

Kombinací kolchicinu a ASA/NSA u AP se zabývaly studie COPE a ICAP, dle kterých přidání kolchicinu k ASA/NSA snižuje riziko rekurencí o polovinu, zkracuje trvání symptomů, zvyšuje množství remisí v prvním týdnu a snižuje počet hospitalizací $(11,12)$. To vše bez zaznamenání významnějších nežádoucích účinků. Kolchicin se podává $v$ dávce 0,5 mg $2 \times$ denně u nemocných s hmotností nad 70 kg a 0,5 mg 1× denně u pacientů vážících méně či netolerujících vyšší dávku. U pacientů s dobrou tolerancí může dávka 1 mg $1 \times$ denně zlepšit compliance. Nasycovací dávce, která byla v minulosti uživána, se vyhýbáme, abychom snižili gastrointestinální vedlejší účinky (průjem, nauzea aj.) a zlepšili pacientovu compliance. Většina autorů preferuje ukončit léčbu kolchicinem až po vysazení ostatních léků (ASA/NSA, ev. kortikoidů). Doporučená doba užívání kolchicinu při AP je na základě výše uvedených studií tři měsíce a není nutné postupné snižování dávky. Během léčby se doporučuje monitorace jaterních testů, krevního obrazu a kreatinkinázy vzhledem k možnosti méně častých (elevace transamináz) či relativně vzácných (útlum kostní dřeně, myotoxicita) nežádoucích účinků. Opatrnost či snižení dávky může vyžadovat současná léčba makrolidovými ATB (zvýšení hladiny kolchicinu) nebo statiny (nárůst rizika myotoxicity). Kolchicin také zvyšuje sérovou koncentraci verapamilu. Účinnost kolchicinu u AP byla demonstrována výlučně v kombinaci s ASA/NSA a/nebo kortikosteroidy. Kolchicin je obvykle účinný u systémových zánětlivých onemocnění a syndromu poškození perikardu. Naopak nebyl prokázán efekt u bakteriální a nádorové perikarditidy. Také u chronického perikardiálního výpotku s normálním CRP není zpravidla účinný (podobně jako ASA/NSA) (1).

Kortikoidy u AP zajistí rychlý ústup symptomů a pokles zánětlivých markerů. Jejich použití je ale spojeno s rizikem chronického průběhu, rekurencí a s větším množstvím nežádoucích účinků. Kortikoidy by proto měly být u AP zvažovány až jako léky druhé volby u nemocných s kontraindikací ASA/NSA (kdy je možné zvážit jejich kombinaci s kolchicinem) Či v prípadě sel- 
hání kombinace ASA/NSA s kolchicinem (kdy je možné zvážit přidání kortikoidů ke stávající protizánětlivé léčbě - „triple“ terapie). Doporučují se podávat v nízkých až středně vysokých dávkách (tzn. prednison 0,2-0,5 mg/kg/den). Počáteční dávku je nutné zachovat do vymizení symptomů a normalizace CRP. Aby se zabránilo rekurencím, musí být jejich následné snižování velmi pozvolné (1). Léčba kortikoidy je dále indikována u autoimunitní a uremické perikarditidy. U neustupující autoimunitní perikarditidy je možná i intraperikardiální aplikace kortikoidů. Mohou být též užitečné při AP v těhotenství a v období laktace (kdy je kontraindikovaný kolchicin, ASA/NSA se nemají podávat po 20. týdnu těhotenství). Kortikoidům bychom se měli vyvarovat, pokud nemůžeme vyloučit možnost bakteriální či tuberkulózní infekce. Při léčbě kortikoidy by měla být zajištěna substituce vápníkem a vitamínem D. Při jejich dlouhodobém podávání v dávkách prednisonu nad 5-7,5 mg/den u mužů nad 50 let a u žen po menopauze jsou doporučeny bisfosfonáty.

$U$ pacientů antikoagulovaných warfarinem je vedení terapie dáno pouze názorem expertů. Aspirin by neměl být podáván, pokud nejsou př́tomny specifické indikace (např. po implantaci stentu). Kolchicin je silně doporučovaný. Často jsou zvažovány nízké dávky kortikosteroidů. V řa-

\section{LITERATURA}

1. Adler Y, Charron P, Imazio M, et al. 2015 ESC Guidelines for the diagnosis and management of pericardial diseases: The Task Force for the Diagnosis and Management of Pericardial Diseases of the European Society of Cardiology (ESC) Endorsed by: The European Association for Cardio-Thoracic Surgery (EACTS). Eur Heat J 2015; 36: 2921-2964. doi: 10.1093/eurheartj/ehv318.

2. Kytö V, Sipilä J, Rautava P. Clinical Profile and Influences on Outcomes in Patients Hospitalized for Acute Pericarditis. Circulation. 2014; 130: 1601-1606.

3. Cremer PC, Kumar A, Kontzias A, et al. Complicated Pericarditis. J Am Coll Cardiol 2016; 68: 2311-2328.

4. Troughton RW, Asher CR, Kein AL. Pericarditis. Lancet 2004; 363: 717-727. dě prípadů je použita nízká dávka NSA. Může být přidán paracetamol či jiná analgetika (1).

U "nevirové a neidiopatické" AP je indikována specifická léčba dle vyvolávající etiologie. Při purulentní perikarditidě je zásadní perikardiocentéza s následnou drenáží perikardiálního vaku a promptní antibiotická léčba (obvykle kombinací antistafylokokového a aminoglykosidového ATB s úpravou dle výsledků mikrobiologických vyšetření). V prípadě adhezí může být zvážena intraperikardiální trombolýza. Často je nutná subxifoidální perikardiotomie s výplachy perikardiálního vaku. V prípadě výrazných adhezí, opakované tamponády, perzistující infekce či progrese do konstrikce musí být zvážena perikardektomie (13). Léčba tuberkulózní perikarditidy by měla být řízena specializovaným pracovištěm. Její součástí je obvykle šestiměsíční aplikace kombinace antituberkulotik. Perikarditidy při renálním selhání reagují zpravidla na zahájení dialyzační léčby, prípadně její intenzifikaci. U syndromu poškození perikardu je účinná empirická protizánětlivá léčba (kombinace ASA či NSA a kolchicin). $\checkmark$ případě nádorové etiologie může dojít k ústupu perikarditidy při systémové chemoterapii a u radiosenzitivních nádorů po ozáření. Velké neoplastické perikardiální výpotky jsou indiko-

5. Spodick DH. Acute pericarditis: curent concept and practice. JAMA 2003; 289: 1150-1153.

6. Imazio M, Demichelis B, Parrini I, et al. Day-hospital treatment of acute pericarditis: a management program for outpatient therepy. J Am Coll Cardiol 2004; 43: 1042-1046. 7. Klein AL, Abbara S, Agler DA, et al. American Society of Echocardiography clinical recommendations for multimodality cardiovascular imaging of patients with pericardial disease: endorsed by the Society for Cardiovascular Magnetic Resonance and Society of Cardiovascular Computed Tomography. J Am Soc Echocardiogr 2013; 26: 965-1012.

8. Imazio M, Adler Y. Management of pericardial effusion. Eur Heart J 2013; 34: 1186-1197.

9. Ben-Horin S, Bank I, Schinfeld A, et al. Diagnostic value of vané k déle trvající drenáži z důvodů zabránění rekurence. $Z$ této indikace může být účinná i intraperikardiální aplikace sklerozující látky. $\checkmark$ prípadě recidivující maligní tamponády může být zvážena perkutánní balonková perikardiotomie se vznikem komunikace mezi pleurou a perikardem a drenáží tekutiny do pleurální dutiny.

\section{Závěr}

$\checkmark$ našich podmínkách představuje AP u velké části postižených pacientů benigní onemocnění s dobrou prognózou. Zásadní význam má její odlišení od vážných kardiovaskulárních patologií spojených s bolestí na hrudi (zejména akutního koronárního syndromu). Velmi důležité je vstupní trídění na rizikové pacienty, u kterých je nutná hospitalizace a stanovení etiologie, a na nemocné s nízkým rizikem, které je možné léčit ambulantně. S cílem redukovat výskyt rekurencí a zkrátit průběh onemocnění by měla být u většiny případů použita dostatečně dlouhá léčba kombinací ASA či NSA a kolchicinu.

Tato práce byla podpořena projektem institucionálního výzkumu MZČR (FN PIzeň, 00669806) a programem podpory rozvoje vědy UK (Progres Q38).

the biochemical composition of pericardial effusions in patients undergoing pericardiocentesis. Am J Cardiol 2007; 99: 1294-1297.

10. Duršpek J, Baxa J, Šedivý J, et al. Should we fear infarct-like myocarditis? Cor et vasa 2018; 60: e607-e614.

11. Imazio M, Bobbio M, Cecchi E, et al. Colchicine in addition to conventional therapy for acute pericarditis: results of the COlchicine for acute PEricarditis (COPE) trial. Circulation 2005; 112(13): 2012-2016.

12. Imazio M, Brucato A, Cemin R, et al. A randomized trial of colchicine for acute pericarditis. N Engl J Med 2013; 369: 1522-1528.

13. Šimek R, Malý J, Telekes P, et al. Purulentní perikarditida. Interv Akut Kardiol 2008; 7(4): 152-154. 